\title{
PERAN LEMBAGA SWADAYA MASYARAKAT TERHADAP PEMBERDAYAAN PEREMPUAN MELALUI PELATIHAN LIFE SKILL (Studi kasus di Lembaga Advokasi Pendidikan Yogyakarta)
}

\author{
Kiromim Baroroh ${ }^{1}$
}

\begin{abstract}
Abstrak
Penelitian ini bertujuan untuk mengetahui: 1) Peran Lembaga Advokasi Pendidikan Yogyakarta (LAPY) dalam memberdayakan perekonomian perempuan, 2) Faktor Pendukung dan Penghambat pemberdayaan perempuan program life skill menjahit.

Penelitian ini menggunakan pendekatan kualitatif. Penelitian dilakukan di kantor LAPY, tempat pelatihan dan tempat usaha/rumah peserta pelatihan Life Skill. Waktu penelitian dilaksanakan selama satu setengah tahun yaitu Januari 2007 sampai Juni 2008. Informan Penelitian : Peserta pelatihan, tutor pelatihan, dan pengurus LAPY. Teknik Pengumpulan Data: Wawancara, Pengamatan dan Dokumentasi . Teknik analisis data yaitu (1) reduksi data; (2) sajian data; dan (3) penarikan kesimpulan atau verifikasi.

Hasil penelitian menunjukkan: 1). Peran LAPY dalam memberdayakan perekonomian perempuan melalui life skill dilakukan melalui pelatihan dan pendampingan menjahit sampai permagangan dan pemberian modal usaha. Disini peran LAPY adalah sebagai fasilitator dan motivator. 2).Faktor pendukung pendampingan program pemberdayaan perempuan: Kerja sama antara pengurus LSM dan masyarakat sasaran, serta adanya pihak ketiga yaitu BMT Bringahrjo yang bersedia memberikan bantuan modal. b. Faktor penghambat: 1).Faktor penghambat yang berasal dari kelompok sasaran program adalah: kurangnya kesadaran dan kemauan untuk menerapkan pengetahuan tentang kewirausahaan, keterbatasan modal untuk meningkatkan penguasaan teknologi, kurangnya kemampuan untuk memanfaatkan dunia usaha karena keraguan UKM untuk meningkatkan usaha,dan kurangnya akses terhadap sumber teknologi dan pengetahuan. 2)Faktor penghambat yang berasal dari LSM: Sistem perekrutan peserta belum dilakukan konsisten sesuai dengan kriteria yang telah ditentukan, pengurus LSM yang mempunyai profesi lain tidak dapat berkonsentrasi memberikan pendampingan, kurangnya relawan yang bersedia melakukan pendampingan secara berkesinambungan.
\end{abstract}

Kata Kunci: LSM, Perempuan, Life Skill

\footnotetext{
${ }^{1}$ Dosen S1 Pendidikan Ekonomi, Pendidikan Ekonomi, FISE UNY
} 


\section{A. Pendahuluan}

Perempuan merupakan bagian tak terpisahkan dalam sebuah masyarakat, tak terkecuali dalam masyarakat miskin. Perempuan memiliki potensi yang sama dengan laki-laki untuk memberikan kontribusi bagi pembangunan masyarakat. Namun pada kenyataannya, perempuan masih belum diberi peran yang lebih, bahkan juga terpinggirkan.

Kiprah perempuan dalam perekonomian keluarga dan nasional menjadi salah satu bagian penting dalam pembangunan secara keseluruhan. Seiring dengan bertambahnya pendapatan perempuan atau akses perempuan terhadap sumber-sumber daya ekonomi melalui usaha ini, maka kemampuan dan kesempatan mereka bernegosiasi dalam rumah tangga pun meningkat. Posisi tawar mereka berubah dan pendapat mereka mulai diperhitungkan dalam setiap proses pengambilan keputusan dalam rumah tangga.

Partisipasi

perempuan merupakan hal yang sangat penting untuk mencapai tujuan pembangunan. Upaya pengembangan usaha mikro yang dilakukan oleh perempuan ini menjadi penting, karena perempuan berhadapan dengan kendala-kendala tertentu yang dikenal dengan istilah "tripple burden of women", yaitu ketika mereka 'diminta' menjalankan fungsi reproduksi, produksi, sekaligus fungsi sosial di masyarakat pada saat yang bersamaan. Hal tersebut menyebabkan kesempatan perempuan untuk memanfaatkan peluang ekonomi yang ada menjadi sangat terbatas.

Sebagian besar perempuan masih berkiprah di sektor informal atau pekerjaan yang tidak memerlukan kualitas pengetahuan dan ketrampilan spesifik. Pekerjaanpekerjaan ini biasanya kurang memberikan jaminan perlindungan secara hukum dan jaminan kesejahteraan yang memadai, disamping kondisi kerja yang memprihatinkan serta pendapatan yang rendah. Beberapa studi mengindikasikan upah perempuan lebih rendah dari laki-laki. Salah satu studi menunjukkan bahwa upah perempuan sekitar $70 \%$ dari upah laki-laki. Dilihat dari akses terhadap kredit, pengusaha perempuan diperkirakan mempunyai akses yang lebih kecil, $11 \%$ dibandingkan lakilaki, $\quad 14 \% .7$ Informasi dari Kementrian Pemberdayaan Perempuan (Hastuti dkk, 2003). Budaya yang cenderung patriarki mengakibatkan perempuan sebagai salah satu kelompok yang termarjinalkan, baik dalam akses pendidikan, kesehatan, dan ekonomi. Guna meningkatkan kesejahteraan perempuan salah satunya adalah melalui pendidikan non formal yaitu pelatihan life skill.

Lembaga

Swadaya

Masyarakat sebagai salah satu elemen penting dalam masyarakat yang dapat membatu terwujudnya pemberdayaan perempuan. Pada hakekatnya kemiskinan dapat berawal dari rendahnya akses pendidikan. Rendahnya akses pendidikan menyebabkan rendahnya akses ekonomi, yang pada akhirnya menyebabkan kemiskinan. 
Salah satu LSM yang peduli akan pemberdayaan perempuan adalah Lembaga Advokasi Pendidikan Yogyakarta. Lembaga (LAPY), terutama bergerak dalam advokasi pendidikan baik pendidikan formal maupun nonformal. Salah satu bentuk pendidikan nonformal dalam pemberdayaan masyarakat adalah pelatihan life skill menjahit bagi perempuan tidak mampu.

Tujuan penelitian ini adalah untuk mengetahui:

1. Peran LAPY dalam memberdayakan perekonomian perempuan.

2. Faktor Pendukung dan penghambat pemberdayaan perempuan program life skill menjahit.

\section{B. Tinjauan Pustaka}

\section{Lembaga Swadaya Masyarakat}

Istilah Lembaga Swadaya Masyarakat (LSM) berasal dari suatu seminar yang diselenggarakan Sekretariat Bina Desa (SBD) di Ungaran, Jawa Tengah 1978. Di kalangan Perserikatan Bangsa-bangsa (PBB), kelompok, lembaga atau organisasi tersebut disebut Non Government Organization (NGO) yang kemudian dalam suatu konferensi (1976) Wahana Lingkungan Hidup (WALHI) diterjemahkan menjadi Organisasi Non Pemerintah (disingkat ORNOP). Namun ada kejanggalan dengan istilah tersebut. Pengertian organisasi Non Pemerintah dapat mencakup berbagai organisasi yang luas (semua organisai yang bukan organisasi Pemerintah) baik organisasi bisnis, kalangan pers, paguyuban seni, olah raga dan lain-lain, padahal dengan NGO yang dimaksud lebih khusus yaitu yang berhubungan langsung dengan pembangunan.

Selanjutnya dalam sejarah pengerakan, kita mengenal istilah "Non" dan "Co". Pada waktu pendudukan Belanda ada kelompok masyarakat yang bekerjasama dengan Belanda disebut "golongan Co" dan ada kelompok yang menolak kerjasama disebut "golongan Non". Istilah NGO dapat diartikan atau dituduh sebagai kelompok masyarakat yang tidak mau bekerjasama dengan Pemerintah. Padahal untuk mencapai tujuan dari kelompok, lembaga atau organisasi tersebut, yaitu meningkatkan keswadayaan dan kemandirian masyarakat yang dilayani, sering perlu banyak bekerjasama dengan Pemerintah.

Dalam mencari istilah Indonesia bagi NGO, ditemukan istilah yang sering dipakai oleh Kementrian Kerjasama International Jerman (Barat) yaitu Self Help Promoting Institute (SHPI) dan Self Help Organization (SHO), masingmasing dimaksudkan sebagai lembaga yang didirikan dengan tujuan menolong yang lain, sedang yang kedua dimaksudkan untuk menolong diri sendiri. Prof. Sayogyo (Bambang Ismawan, 2003), kemudian memperkenalkan istilah Lembaga Pengembangan Swadaya Masyarakat (LPSM) untuk SHPI dan Lembaga Swadaya Masyarakat (LSM) untuk SHO.

Istilah LSM lalu didefinisikan secara tegas dalam Instruksi Menteri Dalam Negeri (Inmendagri) No. 8/1990, yang ditujukan kepada 
gubernur di seluruh Indonesia tentang Pembinaan Lembaga Swadaya Masyarakat. Lampiran II dari Inmendagri menyebutkan bahwa LSM adalah organisasi/lembaga yang anggotanya adalah masyarakat warganegara Republik Indonesia yang secara sukarela atau kehendak sendiri berniat serta bergerak di bidang kegiatan tertentu yang ditetapkan oleh organisasi/lembaga sebagai wujud partisipasi masyarakat dalam upaya meningkatkan taraf hidup dan kesejahteraan masyarakat, yang menitikberatkan kepada pengabdian secara swadaya.

Dalam Pilot Proyek Hubungan

Bank dan Kelompok Swadaya Masyarakat (PPHBK) istilah LSM mencakup pengertian LPSM (Lembaga Pengembangan Swadaya Masyarakat) dan KSM (Kelompok Swadaya Masyarakat). PPHBK yang dikelola oleh Bank Indonesia dimaksudkan menghubungkan Bank (formal) dengan KSM (non formal) dalam bidang permodalan. Sejak diperkenalkan Bank Indonesia tahun 1988, skema HBK telah berjalan sangat baik, hingga September 2001, dilaksanakan di 23 propinsi, mencakup lebih dari 1000 kantor bank partisipan, 257 LPSM, 34.227 kelompok swadaya masyarakat dengan anggota sekitar 1.026.810 KK, menyalurkan kredit (akumulasi) Rp 331 milyar, memobilisasi tabungan beku (akumulasi) Rp 29,5 milyar, dan tingkat pengembalian kredit 97,3\%.

Dari uraian diatas dapat disimpulkan bahwa pengertian LSM mencakup dua kategori yaitu KSM dan LPSM. Disamping itu ada kategori ketiga yang disebut LSM
Jaringan, yaitu suatu bentuk kerjasama antara LSM dalam bidang kegiatan atau minat tertentu, misalnya :

1) Sekretariat Bina Desa (SBD), berdiri 1974, merupakan forum dari LSM yang bekerja di kawasan pedesaan

2) Wahana Lingkungan Hidup (WALHI), berdiri 1976, merupakan wadah kebersamaan LSM yang memusatkan perhatian pada upaya pelestarian lingkungan

3) Forum Indonesia untuk Keswadayaan Penduduk (FISKA), berdiri 1983, merupakan forum LSM yang bergerak dibidang kependudukan

4) Forum Kerjasama Pengembangan Koperasi (FORMASI), berdiri 1986, merupakan forum LSM yang bekerja mengembangkan koperasi

5) Forum Pengembangan Keswadayaan (Participatory Development Forum- PDF), berdiri 1991, merupakan peningkatan dari Forum Kerjasama LSM PBB (NGO - UN Cooperation Forum) yang didirikan pada 1988. PDF menggabungkan berbagai LSM berinteraksi dengan Pemerintah, dunia usaha dan badan-badan Internasional dalam suatu forum untuk mengembangkan peran serta berbagai aktor dalam pembangunan

6) Forum LSM Yogyakarta, salah satu contoh LSM yang bergerak di dalamnya adalah Lembaga Advokasi Pendidikan Yogyakarta. 


\section{LSM, Pendidikan, dan Kemiskinan}

Pendidikan untuk penyadaran dapat tercipta apabila pendidikan itu dilangsungkan dengan semangat yang membebaskan. Pendidikan yang membebaskan setidaknya memberi ruang bagi sosial pendidikan yang secara kritis mempertanyakan struktur ekonomi, politik, perangkap social, gender, serta hak asasi manusia.

Ketika pendidikan dinggap sebagai suatu fondasi yang sangat subtansial dalam segala aspek kehidupan, maka pendidikan dapat memainkan peran yang penting untuk sebuah perubahan atau transformasi social politik menuju ke suatu social yang lebih demokratis dan adil. Sebaliknya pendidikan juga terkadang dapat dan sering digunakan sebaga alat untuk melegitmasi sosial dan struktur politik yang ada.

Satu hal yang membuat hal miris adalah bila melihat kenyataan kelas ekonomi rendah yang tidak bisa melanjutkan pendidikan ke jenjang yang lebih tinggi padahal mereka mempunyai kemampuan dan prestasi yang cukup. Pada dasarnya mereka juga berhak mendapatkan pendidikan yang layak dan mereka merupakan socia bangsa ke depan untuk membawa bangsa lebih maju. Memperhatikan hal ini, maka peran dari LSM sangat diperlukan sebagai satu elemen masyarakat yang memberikan proses penyadaran dalam dalam upaya pemberdayaan masyarakat.

Aspek yang dianggap penting dalam pendekatan ini antara lain adalah adanya usaha untuk mengurangi kesenjangan social dengan meningkatkan kapabilitas sumber daya manusia, terutama pada kelompok-kelompok masyarakat yang meupakan penduduk miskin. Upaya-upaya yang ditempuh di dalam pendekatan ini melalui pembangunan infrastruktur pedesaan, distribusi social ekonomi dan modal usaha/kerja serta penguatan kelembagaan masyarakat. Beberapa program yang mendukung pendekatan pemberdayan masyarakat dan cukup dikenal semenjak tahun 1994 adalah:

$>$ Inpres Desa Tertinggal (IDT).

$>$ Pembangunan prasarana Pendukung Desa Tertinggal (P3DT)

$>$ Kecamatan Program Pembangunan (KPP)

$>$ Program Penanggulangan Kemiskinan Perkotaan (P2KP)

$>$ Jaring Pengaman Sosial (JPS)

> Bantuan Operasional Sekolah (BOS)

Dalam kenyataannya meski sering tidak optimal, ternyata juga tidak mengecewakan. Meski demikian pada saat bersamaan, pendekatan ini juga tidak kedap terhadap berbagai kritik dan kecaman. Sifatnya yang top-down atau project oriented adalah salah satu kritik yang dilontarkan banyak pihak. (Hari Susanto, 2006: 25).

\section{Peran LSM Pendidikan dalam Pemberdayaan masyarakat}

Peran LSM sebenarnya tidak terlepas dari sejarah berdirinya bangsa ini. LSM jaman penjajahan didirikan dengan motivasi membebaskan diri daari kungkungan penjajahan dengan upaya pendidikan 
dan usaha di bidang ekonomi . mengapa LSM saat konsen pada masalah pendidikan?

Pendidikan memegang peranan yang cukup penting sebagai media penyadaran masyarakat. Bermula dari kesadaran inilah kemudian bisa berlanjut ke kerjakerja pemberdayaan seperti advokasi pendidikan dan pengorganisasian masyarakat. Melihat hal tersebut masyarakat harus membangun komitmen bersama dalam menyelamatkan pendidikan yang sarat dengan kepentingan dengan melakukan advokasi dalam lingkungan pendidikan dan melakukan advokasi pendidikan di masyarakat.

Asumsi yang mendasaari penggunaan strategi advokasi adala bahwa suatu perubahan social yang lebih besar dan luas dapat terjadi (atau paling tidak dapat dimulai) dengan merubah satu per satu kebijakan publik yang memang strategis atau sangat menentukan dalam kehidupan masyarakat luas.

$$
\text { Rekonstruksi komitmen }
$$

bersama dalam menyelamatkan "pendidikan" dengan melakukan advokasi adalah ada beberapa hal yang perlu dilakukan yakni; pertama adanya transformasi wacana advokasi pendidikan di masyarakat sebagai skill bagi masyarakat sebagai upaya penyadaran diri dan ikut memperjuangkan hak-haknya dalam pendidikan, kedua, pembentukan jaringan sebagai wadah pendukung perjuangan dalam melakukan advokasi di lingkungan pendidikan dan advokasi pendidikan di masyarakat dan ketiga, adalah pemberdayaan dan penguatan pendidikan di masyarakat sebagai upaya advokasi yang perlu dilakukan. Sehingga sebagai media penyadaran, pendidikan dapat berperan sebagai counter hegemony dari budaya dan social dalam masyarakat.

Dengan

memahami

rekonstruksi unsur-unsur

pemberdayaan, dapatlah kemudian disusun program-program pengembangan yang merupakan peran LSM untuk mendorong keberhasilan penyelenggaraan kelompok swadaya. Bambang Ismawan (2003) mengemukakan ada 5 (lima) program pengembangan yang dapat disusun untuk mendorong keberhasilan kelompok swadaya yang disalurkan melalui tenaga-tenaga pendamping kelompok, yaitu :

a. Program Pengembangan sumber daya manusia, meliputi berbagai kegiatan pendidikan dan latihan baik pendidikan dan latihan untuk anggota maupun untuk pengurus yang mencakup pendidikan dan latihan tentang ketrampilan mengelola kelembagaan kelompok, ketrampilan teknik produksi, maupun ketrampilan mengelola usaha.

b. Program pengembangan kelembagaan kelompok, dengan membantu menyusun peraturan rumah tangga, mekanisme organisasi, kepengurusan, administrasi dan lain sebagainya.

c. Program pemupukan modal swadaya, dengan membangun social tabungan dan kredit anggota serta menghubungkan kelompok swadaya tersebut 
dengan lembaga-lembaga keuangan setempat untuk mendapatkan manfaat bagi pemupukan modal lebih lanjut.

d. Program pengembangan usaha, baik produksi maupun pemasaran, dengan berbagai kegiatan studi kelayakan, informasi pasar, organisasi produksi dan pemasaran dan lain-lain.

e. Program penyediaan informasi tepat guna, sesuai dengan kebutuhan kelompok swadaya dengan berbagai tingkat perkembangannya. Informasi ini dapat berupa eksposure program, penerbitan buku-buku maupun majalah-majalah yang dapat memberikan masukan-masukan yang mendorong inspirasi ke arah inovasi usaha lebih lanjut.

Membawakan peran nyata dalam pembangunan pendidikan, dengan menyelenggarakan kegiatankegiatan tersebut di atas, keberadaan LSM akan berdampak positif seperti diuraikan dibawah ini:

Dampak dalam aspek social diketahui melalui proses pendidikan yang diberikan kepada kelompok swadaya diharapkan wawasan pemikiran mereka pun semakin meningkat; sehingga mempunyai kemampuan untuk memikirkan banyak alternatif dalam usaha mencukupi kebutuhan hidup. Peningkatan pendidikan yang terjadi pada kelompok swadaya dapat melalui dua jalur, yaitu secara langsung dan tidak langsung. Peningkatan pendidikan secara langsung terjadi apabila kelompok swadaya mendapatkan penyuluhan, pelatihan, konsultasi, dan sebagainya. Sedangkan, peningkatan pendidikan secara tidak langsung terjadi sejalan dengan terintegrasinya orang-orang desa dalam suatu kelompok swadaya. Melalui kelompok tersebut setiap anggota berinteraksi menumbuhkan kesadaran akan posisi mereka. Penyadaran diri merupakan langkah awal untuk memulai memikirkan alternatif-alternatif baru yang mungkin dapat ditempuh dalam usaha memperbaiki tingkat kehidupan. Di samping itu, dengan adanya kesadaran akan posisi yang dimilikinya menyebabkan kelompok swadaya berani memperjuangkan hak-hak mereka dengan mengaktualkan potensi yang ada pada mereka serta mengikis kelemahan-kelemahan yang ada.

Melalui aktifitas yang dilakukan, intervensi pembinaan membantu pemecahan permasalahan-permasalahan sosial yang terdapat dalam kelompok masyarakat. Melalui sistem pendekatan terlibat langsung dengan kelompok, pola pembinaan bersama kelompok yang bersangkutan mampu mengidentifikasikan permasalahan yang dihadapi secara mendalam. Akibatnya penanganan terhadap masalah yang dihadapi kelompok dapat dilakukan secara tepat sasaran dan lebih tuntas. Di Samping itu, berkat interaksi yang intens antara para pembina dengan kelompok, sementara para pembina telah dilatih secara khusus dan selalu diberikan masukan untuk meningkatkan kemampuannya dalam membina kelompok dan menghubungkannya dengan 
berbagai pelayanan setempat, maka terjadilah proses transformasi sosial.

Adapun dampak dalam Aspek Kemasyarakatan dinyatakan bahwa proses interaksi didalam kelompok dengan sesama anggota maupun dengan berbagai sumber pelayanan dan pembinaan semakin meningkatkan wawasan berbangsa dan bernegara. Adanya kelompok sebagai wadah mengaktualisasikan diri warga masyarakat pedesaan menyebabkan mereka merasa terlibat dalam proses pembangunan. Keterlibatan mereka dalam pembangunan tidak lagi pasif, tetapi menjadi aktif karena telah turut berusaha dalam berbagai kegiatan produktif yang memberikan andil dalam sistem perekonomian yang lebih luas.

Kesadaran untuk turut berperan serta dalam kegiatan kelompok tersebut mempunyai dampak lebih lanjut, yaitu adanya kesediaan mereka untuk berpartisipasi dalam programprogram pembangunan yang ditawarkan pemerintah. Proses pengembangan kemandirian dan kesadaran berpartisipasi telah menjembatani kesenjangan sosial di tingkat lokal. Dengan menyempitnya kesenjangan sosial berarti stabilitas sosial politik pun dapat terus berlanjut. Sementara itu, pengalaman lapangan LSM yang merupakan hasil kaji tindak (participatory action research) dapat merupakan rekomendasi bagi perbaikan dan peningkatan dari pendekatan pembangunan.

Dampak dalam Aspek Ekonomi diketahui, intervensi pembinaan akan mampu mendorong masyarakat kecil untuk melakukan pemupukan modal. Selama ini faktor yang selalu dikemukakan tentang penyebab tidak berhasilnya masyarakat miskin dalam memperbaiki kehidupan adalah karena mereka tidak mampu untuk melakukan pemupukan modal yang dapat dipergunakan sebagai pengembangan usaha. Dengan sistem kelompok, maka modal yang kecil dari setiap warga dapat berkembang menjadi besar, sehingga dapat dipergunakan sebagai modal usaha. Di samping itu, dengan adanya modal yang terkumpul dapat mengundang partisipasi dana lebih besar dari pihak ketiga. Saat ini terbuka kemungkinan Bank melayani kelompok-kelompok swadaya yang berstatus non formal. Kemampuan permodalan kelompok yang semakin bertambah memberikan peluang semakin besar untuk mengembangkan usaha produktif.

$$
\text { Usaha produktif yang }
$$
dilakukan kelompok menyebabkan terbukanya kesempatan kerja atau usaha bagi kelompok itu sendiri maupun masyarakat luas. Hal ini berdasarkan kenyataan bahwa satu usaha produktif yang dilakukan, misalnya peternakan atau industri kecil, tentu memerlukan usaha lain untuk menunjang keberhasilan usaha produktif pokok. Usaha-usaha lain dari usaha pokok inilah yang membuka kesempatan kerja baru (diversifikasi) dan peningkatan pendapatan warga masyarakat. Dengan upaya ini diharapkan tingkat kemiskinan dapat ditekan serendah mungkin. 


\section{Life Skill}

Kecakapan hidup (life skill) adalah kecakapan yang dimiliki seseorang untuk berani meng- hadapi problema hidup dan kehidupan secara wajar tanpa merasa tertekan, kemudian secara proaktif dan kreatif mencari serta menemukan solusi sehingga akhirnya mampu mengatasinya. Kecakapan hidup lebih luas dari keterampilan untuk bekerja, apalagi sekedar keterampilan manual. Orang yang sedang menempuh pendidikan juga memerlukan kecakapan hidup, karena mereka tentu juga memiliki permasalahan yang harus dipecahkan. Bukankah dalam hidup, dimanapun dan kapanpun orang selalu menemui masalah yang harus dipecahkan. Kecakapan hidup dapat dipilah menjadi lima, yaitu :

a. kecakapan mengenal diri (self awarness), yang juga sering disebut kemampuan personal (personal skill)

b. kecakapan berpikir rasional (thinking skill)

c. kecakapan sosial (social skill)

d. kecakapan akademik (academic skill), dan

e. kecakapan vokasional (vocational skill)

Maka pembekalan kecakapan hidup dan 8 penggalian potensi diri sangat dibutuhkan sebagai dasar perancangan kurikulum. Adapun 8 penggalian potensi diri tersebut adalah:
a. kemampuan matematis,
b. kemampuan bahasa,
c. kemampuan musikal,
d. kemampuan visual,
e. kemampuan intrapersonal,
f. kemampuan interpersonal,

g. kemampuan kinetis,

h. kemampuan natural. (Suranto, 2006)

Dalam kecakapan hidup pelatihan menjahit ini kemampuan utama yang harus dilatih adalah kemampuan matematis, visual, dan kinetis. Kemampuan intrapersonal dan interpersonal juga perlu diperhatikan karena terkait dengan kepuasan pelanggan.

\section{Metode Penelitian}

1. Pendekatan Penelitian

Penelitian ini menggunakan pendekatan kualitatif di mana peneliti menekankan pada manusia serta melihat secara langsung keadaan yang ada tanpa mengubah peristiwa yang terjadi di lapangan, dan setelah di rumah peneliti membuat catatan lapangan, seperti yang dikatakan Lincoln dan Guba (1985 : 40) bahwa penelitian kualitatif digunakan untuk dapat menjelaskan atau mengungkapkan secara langsung atau alamiah apa yang terjadi di lapangan. Oleh karena itu peneliti dapat secara langsung menginventarisasi data dari peserta pelatihan, tutor pelatihan, dan pengurus Lembaga Advokasi Pendidikan Yogyakarta.

\section{Setting Penelitian}

Penelitian dilakukan di kantor LAPY, tempat pelatihan dan tempat usaha/rumah peserta pelatihan Life Skill.

\section{Waktu dan Lama Penelitian Waktu penelitian dilaksanakan selama satu setengah tahun yaitu Januari 2007 sampai Juni 2008.}




\section{Informan Penelitian}

Peserta pelatihan, tutor pelatihan (ibu Jilli), Ibu R (penjahit tempat magang), dan $\mathrm{W}, \mathrm{Q}$, dan $\mathrm{S}$, pengurus Lembaga Advokasi Pendidikan Yogyakarta.

\section{Teknik Pengumpulan Data}

Dalam penelitian ini teknik pengumpulan data yang digunakan adalah:

a. Wawancara

Wawancara adalah dengan maksud tertentu yang dilakukan oleh dua pihak yaitu pewawancara (interviewer) dan yang diwawancarai (intererviewee) (Moleong, 2004: 135). Wawancara dimaksudkan untuk mengumpulkan data dengan berdialog dengan informan. Peneliti melakukan wawancara sehingga terjadi hubungan yang akrab antara peneliti dengan yang diwawancarai. Dengan keadaan yang demikian peneliti dapat mengembangkan pertanyaan agar dapat memperoleh informasi yang rinci, jujur dan mendalam. Wawancara seperti ini dalam penelitian kualitatif dikenal dengan wawancara mendalam (in-depth interview). Peneliti menggunakan waancancaara informal.

Pada penelitian ini, peneliti menggunakan pendekatan wawancara informal dan pendekatan menggunakan petunjuk umum wawancara (Patton, 1982: 197). Pada pendekatan wawancara informal pertanyaan yang diajukan sangat tergantung pada pewawancara sendiri (Moleong, 2004: 136). Sementara pendekatan dengan petunjuk umum wawancara digunakan atas anggapan bahwa ada jawaban yang secara umum akan sama diberikan oleh para responsden, tetapi yang jelas tidak ada perangkat pertanyaan baku yang disiapkan terlebih dahulu (Moleong, 2004: 136). Dalam penelitian kualitatif peneliti adalah alat pengumpul data yang utama. Oleh karena itu agar informasi yang diberikan oleh informasi bisa dicatat dengan baik akan digunakan catatan lapangan dan tape recorder.

b. Pengamatan

Pengamatan adalah teknik pengumpulan data dengan mengamati objek penelitian secara langsung. Dalam penelitian kualitatif, pengamatan dimanfaatkan untuk (1) pengamatan didasarkan atas pengalaman secara langsung; (2) pengamatan memungkinkan melihat dan mengamati sendiri, kemudian mencatat perilaku dan kejadian dalam keadaan yang sebenamya; (3) pengamatan memungkinkan mencatat peristiwa dalam situasi yang berkaitan dengan pengetahuan proporsional; (4) ada keraguan jangan-jangan data yang dijaring melenceng atau bias, dan perlu dicek dengan pengamatan; memungkinkan peneliti mampu memahami situasi yang sulit; (6) dalam kasus-kasus tertentu di mana teknik lain tidak memungkinkan, maka dapat digunakan pengamatan (Lincoln dan Guba, 1985: 125-126).

c. Dokumentasi

Menurut Lincoln dan Guba (1985 : 228) dokumentasi adalah setiap bahan tertulis ataupun film. Sedangkan record adalah setiap pernyataan tertulis yang disusun oleh seseorang atau lembaga untuk keperluan pengujian suatu peristiwa 
atau menyajikan akunting. Teknik dokumentasi dimanfaatkan untuk mengadakan verifikasi dan triangulasi data yang diperoleh melalui observasi dan wawancara.

6. Analisis Data

Teknik analisis data adalah salah satu aspek yang dilakukan untuk mendapatkan makna dari kumpulan data. Dalam penelitian kualitatif ada tiga langkah dalam menganalisis data, yaitu (1) reduksi data; (2) sajian data; dan (3) penarikan kesimpulan atau verifikasi (Miles dan Huberman, 1994: 10-12). Ketiga komponen dalam analisis data tersebut selalu berkaitan antara satu dengan yang lain. Dalam penelitian ini peneliti menggunakan analisis selama pengumpulan data.

7. Uji Keabsahan Data

Peneliti dalam memeriksa keabsahan data menggunakan teknik trianggulasi data. Adapun triangulasi yang digunakan dalam penelitian ini adalah sebagai berikut:

1) Trianggulasi Sumber

Trianggulasi sumber atau data adalah membandingkan dan mengecek balik derajat kepercayaan suatu informasi yang diperoleh melalui waktu dan alat yang berbeda dalam metode kulaitatif. Menurut Moleong (2004: 178) hal ini dapat dicapai dengan jalan: (1) membandingkan data hasil pengamatan dengan data hasil wawancara, (2) membandingkan apa yang dikatakan orang di depan umum dengan apa yang dikatakannya secara pribadi, (3) membandingkan apa yang dikatakan orang-orang tentang situasi penelitian dengan apa yang dikatakannya sepanjang waktu, (4) membandingkan keadaan dan perspektif seseorang dengan berbagai pendapat dan pandangan orang sebagai rakyat biasa, orang yang berpendidikan menengah atau tinggi, orang berada, orang pemerintahan, (5) membandingkan hasil wawancara dengan isi suatu dokumen.

2) Triangulasi metode Menurut Patton (1982: 329), terdapat dua strategi yaitu: (1) pengecekan derajat kepercayaan penemuan hasil penelitian beberapa teknik pengumpulan data dan (2) pengecekan derajat kepercayaan beberapa sumber data dengan metode yang sama.

\section{Hasil Penelitian Dan Pembahasan \\ 1. Profil LSM}

Lembaga ini didirikan pada tahun 1999 dengan nama Lembaga Advokasi pendidikan UNY (LAP UNY). Diawal kiprahnya lembaga ini memberikan advokasi pada mahasiswa UNY. Seiring berjalannya waktu pada tahun 2000 LAP UNY berganti nama menjadi Lembaga Advokasi Pendidikan Yogyakarta (LAPY), yang menuntut fungsi dan tugas lembaga dapat dimanfaatkan secara lebih luas oleh masyarakat. LAPY tercatat di notaris Muhammad Ikhwanul Muslimin dengan nomer 01 tahun 2001, diketuai oleh Adullah Syafii.

Saat ini ketua lembaga dipegang oleh adalah W (27). Profesi keseharian $\mathrm{W}$ adalah wirausaha. W mempunyai usaha boga,laundry dan sewa kamar kos. W sudah menikah dan mempunyai seorang anak laki- 
laki. Pendidikan terakhir S1 Sastra Inggris.

Q(27)) sebagai bendahara. Profesi kesehariannya adalah sebagai dosen disebuah PTN. Masih single. Pendidikan S2 PTN. Q juga termasuk pendiri LSM ini.

$S$ (26) sebagai koordinator program profesi utamanya adalah pegiat LSM Lingkar. Saat ini sedang menempuh S2, status masih lajang.

Ketiga pengurus ini bekerja paruh watu secara sukarela. Mereka tidak mendapatkan gaji dari lembaga ini. Ketika peneliti menanyakan apakah perlu transport untuk kegiatan mereka, S menyatakan tidak perlu LSM ini membayar mereka meskipun sekedar transpor. Hal ini untuk memberikan motivasi kepada pengurus bahwasannya di LSM ini, mereka tidak bertujuan untuk mencari uang.

\section{Pelaksanaan pendampingan}

Kelompok sasaran pelatihan ini adalah para ibu rumah tangga dan remaja putus sekolah berjumlah 11 orang, Berikut ini tabel tentang profil peserta

pendampingan:

Tabel 1. Profil Peserta Pendampingan

\begin{tabular}{|l|l|l|}
\hline Nama & Usia & Alamat \\
\hline A & 45 & Bantul \\
\hline B & 25 & Sleman \\
\hline C & 18 & Sleman \\
\hline D & 19 & Kulonprogo \\
\hline E & 19 & Kulonprogo \\
\hline F & 25 & Kulonprogo \\
\hline G & 24 & Sleman \\
\hline H & 24 & Sleman \\
\hline I & 23 & Sleman \\
\hline J & 23 & Sleman \\
\hline K & 23 & Sleman \\
\hline
\end{tabular}

Pemberdayaan perempuan melalui pelatihan life skill dimulai pada Januari 2007. Pada awalnya dengan adanya pelatihan menjahit bagi perempuan peserta yang terdaftar sebanyak 11 orang. Dari awal yaitu kursus menjahit dan magang. Anggota penjahit LAPY berasal dari Kulonprogo (3 orang), Bantul (1 orang) dan Sleman (7 orang). Kegiatan ini dilakukan secara berkesinambungan.

Mereka direkrut oleh LAPY. Kegiatan ini bekerja sama dengan
BMT Bringharjo. BMT Bringharjo memberikan bantuan modal untuk kegiatan life skill. Kegiatan yang ditawarkan adalah menjahit. Perekrutan dengan melibatkan masyarakat dampingan LAPY. Peserta yang dilibatkan harus memenuhi syarat: perempuan, usia produktif, tidak mampu, dan bersedia mengikuti pelatihan secara aktif sampai akhir pelatihan.

Kegiatan dimulai dengan kegiatan menjahit selama satu bulan di penjahit Jilli. Masing-masing 
peserta didampingi secara individu, mengingat kemampuan peserta yang berbeda. Kegitan kursus dilakukan setiap hari senin sampai sabtu, dengan waktu yang fleksibel disiang hari. Setiap minggu dilakukan evaluasi oleh pengurus LAPY dengan penjahit Jilli. Menurut $\mathrm{W}$ ini dilakukan untuk melihat perkembangan para peserta.

Di akhir kursus diadakan evaluasi. Dalam menjahit ini Ibu A memperoleh predikat terbaik. Ibu A memang pernah bekerja di konveksi, namun belum lancar menjahit. Setelah mendapat pelatihan selama sebulan Ibu A sudah mampu menjahit pakaian wanita/pria. Diantara peserta hanya Ibu A yang percaya diri untuk mendirikan usaha sendiri.

Sepuluh peserta berhasil lulus dari kursus Ibu Jilli dan mendapatkan sertifikat ketrampilan menjahit. Satu orang yaitu K mempunyai kelemahan dalam menjahit. Ini diakui oleh Ibu Jilli, apabila peserta yang lain cukup terampil setelah diberi bimbingan $\mathrm{K}$ selalu mengeluh dan merasa tidak mampu melakukan kegiatan menjahit. Untuk mengukur dan menggunting masih perlu pendampingan yang intensif. Sepuluh peserta yang lain sudah dapat dilepaskan oleh Ibu Jilli, namun untuk $\mathrm{K}$ perlu didampingi. Akhirnya Ibu Jilli merasa kewalahan mengajar K. Dan tidak merekomendasikan $\mathrm{K}$ untuk mengikuti permagangan kecuali dia mempunyai kemauan yang keras. $\mathrm{K}$ pun juga sudah merasa tidak mampu mengikuti kegiatan permagangan. $\mathrm{K}$ memang berada di bawah rata-rata teman-temannya. K diikutkan karena anak tokoh masyarakat. Orang tuanya menyuruh dia untuk ikut berkegiatan. Orang tuanya juga berasal dari orang yang mampu, tidak seperti peserta yang lain, yang berasal dari keluarga kurang mampu.

Guna menambah wawasan peserta dalam menjahit agar tumbuh rasa percaya diri, maka LAPY mengadakan kegiatan permagangan. Permagangan ini diikuti oleh delapan peserta. Kegiatan permagangan di tempat yang dekat dengan peserta. Permagangan ini dimaksudkan untuk menambah keterampilan para peserta.

Ketika peneliti berkunjung ditempat B dan C magang. Mereka diberi kepercayaan untuk menjahit baju yang dipesan. Awalnya mereka belum boleh memotong sendiri karena kegiatan memotong ini adalah kegiatan yang sangat menentukan dalam proses menjahit baju. Apabila salah memotong maka proses selanjutnya akan terhambat. Menurut Ibu R(penjahit) $B$ sudah dapat dipercaya. B juga aktif masuk, berbeda dengan $C$. $C$ hanya pernah masuk dua kali, selanjutnya tidak pernah masuk lagi. Ketika dikonfirmasikan $\mathrm{C}$ merasa tempatnya magang terlalu jauh (berjarak $10 \mathrm{~km}$ dari rumahnya).

Setelah selesai permagangan selama dua bulan para peserta diberi bantuan empat mesin jahit. Satu mesin jahit untuk Ibu A (karena rumahnya sendiri, berjauhan dari anggota yang lain), B,C,F,G,H,K diberikan dua mesin jahit, dan $\mathrm{D}, \mathrm{E}$ satu mesin jahit. Pengadaan mesin jahit tersebut dilengkapi dengan pengadaan bahan baku seperti 
benang. Ini dilakukan dengan harapan para peserta mampu mengaplikasikan keterampilan dari kursus. Mereka diaharapkan dapat menjalankan usaha sendiri atau bekerja pada orang lain. Mesin jahit yang diberikan digunakan sebagai dana bergulir. Dari empat mesin jahit yang ada, tiga mesin jahit telah dilunasi oleh peserta. Ada satu peserta yaitu ibu A yang tidak bersedia melunasi mesin jahit tersebut. Menurut S, ibu A selalu berkilah apabila diminta membayar mesin jahit tersebut.

Setelah satu tahun berjalan ternyata dari 9 peserta yang masih tetap menerima jahitan ada 3 yaitu Ibu A, B, dan I. B berani menerima jahitan karena Ibu $\mathrm{R}$, penjahit yang menjadi tempat magang bersedia memfasilitasi apabila ada kesulitan dalam mengerjakan pesanan pelanggan. Ibu A masih bersedia menerima jahitan, namun lebih suka mengerjakan membuat sprei dan cover bantal guling, mukena, dan jilbab payet dengan cara mengambil bahan baku dari pengepul.

Melihat hal ini memang diakui oleh pengurus LAPY bahwasannya tidak sepenuhnya dapat mendampingi para penjahit ini. Menurut W, keterbatasan SDM dalam memberdayakan perempuan ini memang masalah terbesar. Mengingat pengurus mempunyai profesi di luar sebagai pegiat LAPY.

Ketika selesai magang para peserta pelatihan diberi kepercayaan untuk memilih usaha sendiri atau bekerja pada penjahit/usaha konveksi yang sudah profesional. Para perempuan peserta pelatihan ternyata masih mempunyai hambatan dalam menjalankan usaha ini antara lain:sebagian peserta kurang memiliki kesadaran untuk menerapkan pengetahuan yang dimiliki tentang wirausaha menjahit ini. Mereka masih enggan untuk menggunakan pengetahuan ini dalam usaha mereka. F mengaku belum percaya diri untuk memulai usaha ataupun bekerja pada perusahaan/penjahit.

Keterbatasan modal ternyata masih diakui oleh peserta. Ibu A mengaku modal yang didapat habis untuk memenuhi kebutuhan seharihari. Modal yang diberikan oleh LAPY berupa bahan baku ketika habis digunakan untuk menerima jahitan. Uang hasil jahitan tidak digunakan untuk modal selanjutnya, namun untuk kegitan konsumsi.

Berbeda dengan Ibu A, E tidak terlalu berani untuk mamanfaatkan peluang usaha. Di daerah D dan E tinggal masih jarang yang bekerja sebagai penjahit. Disana juga banyak anak sekolah. D berusaha sedikit demi sedikit menerima jahitan. Pada langkah awal E menerima jahitan yang mudah. Satu jahitan hem D diberi upah Rp. 16.000. Berbeda dengan D, E merasa kurang percaya diri untuk menjalankan usaha menjahit. E merasa ragu untuk menerima jahitan.

B setelah magang, selain menerima jahitan sendiri. Dia masih bekerja di Ibu R. B juga sudah berani menjahit celana panjang. Kesulitan B pada permodalan karena belum memiliki mesin itik dan obras, sehingga kalau ada pesanan harus pergi ke rumah ibu $\mathrm{R}$, dan mengantri mesin obras dan itik. 


\begin{abstract}
Akses terhadap sumber pengetahuan ternyata juga menyebabkan E tidak percaya diri untuk membuka usaha. Meskipun Ibu Jilli selalu menawrkan memberi bantuan. E diminta untuk menerima jahitan dari tetangga E. Apabila E mempunyai kesulitan dapat berkonsultasi dengan Ibu Jilli, namun E merasa akses informasi yaitu ke tempat Ibu Jilli terlalu jauh.
\end{abstract}

Dengan demikian faktor pengahambat dalam pemberdayaan perempuan khususnya dalam pelatihan life skill ini adalah: 1) kurangnya kesadaran dan kemauan untuk menerapkan pengetahuan tentang kewirausahaan, (2) keterbatasan modal untuk meningkatkan penguasaan teknologi, (3) kurangnya kemampuan untuk memanfaatkan peluang usaha karena keraguan UKM untuk meningkatkan usaha (4) kurangnya akses terhadap sumber teknologi dan pengetahuan.

Hambatan dari pihak LSM diketahui, pengurus sekaligus sebagai pengelola program. Ini diakui oleh W dirasa kurang efektif dalam menjalankan program pemberdayaan. W mengungkapkan seharusnya pengelola program pendampingan ini dibentuk tim teknis yang dapat bekerja secara maksimal. Namun karena keterbatasan anggaran hal ini dirasa tidak memungkinkan.

Kegiatan pengurus di luar LSM yakni dengan profesi yang tidak berhubungan langsung dengan LSM ini juga turut menjadi penghambat. Waktu yang tersedia untuk melakukan pendampingan dirasa tidak mencukupi.

\section{E. Kesimpulan}

1. Peran LAPY dalam memberdayakan perekonomian perempuan melalui life skill diketahui melalui pelatihan dan pendampingan menjahit. Pendampingan pemberdayaan tidak hanya berhenti pada pelatihan. Namun sampai permagangan dan pemberian modal usaha. Disisni peran LAPY adalah sebagai fasilitator dan dinamisator. Namun masih ada kekurangan karena ternyata masih memerlukan pendamping yang intensif untuk dapat mendampingi para perempuan yang menjadi sasaran program pemberdayaan perempuan.

2. Faktor Pendukung dan Penghambat pendampingan program pemberdayaan perempuan.

a. Faktor pendukung pendampingan program pemberdayaan perempuan:

1) Kerja sama antara pengurus LSM dan masyarakat sasaran

2) Adanya pihak ketiga yaitu BMT Bringahrjo yang bersedia memberikan bantuan modal

b. Faktor penghambat

Faktor penghambat dibedakan antara faktor pengahmbat yang berasal dari LSM selaku penyelenggara dan Kelompok masyarakat sasaran .

1).Faktor penghambat yang berasal dari kelompok sasaran program adalah:

a) kurangnya kesadaran dan kemauan untuk menerapkan pengetahuan tentang kewirausahaan,

b) keterbatasan modal untuk meningkatkan penguasaan teknologi,

c) kurangnya kemampuan untuk memanfaatkan dunia 
usaha karena keraguan UKM untuk meningkatkan usaha

d) kurangnya akses terhadap sumber teknologi dan pengetahuan.

2) Faktor pengambat yang berasal dari LSM

a) Sistem perekrutan peserta belum dilakukan konsisten sesuai dengan kriteria yang telah ditentukan. Sehingga ada peserta yang tidak sesuai dengan kriteria seperti hanlnya $\mathrm{K}$ yang sebenarnya tidak layak untuk mengikuti pelatihan karena berasal dari orang mampu.

b) pengurus LSM, yang mempunyai profesi lain tidak dapat berkonsentrasi memberikan pendampingan

c) Kurangnya relawan yang bersedia melakukan pendampingan secara berkesinambungan.

c. Saran

1. sistem perekrutan hendaknya dilaksanakan secara konsisten sesuai dengan kriteria yang ditentukan

2. hendaklah melibatkan relawan yang bersedia melakukan pendampingan secara berkesinambungan. Tentunya perlu dialokasikan dana khusus untuk relawan ini.

3. peserta pendampingan (UMKM) hendaklah mempunyai motivasi tinggi untuk melakukan kegiatan, setiap ada permasalahan hendaklah dikomunikasikan dengan tutor, tidak perlu malu atau sungkan.

\section{Daftar Pustaka}

Anonim (2004). Daerah Istimewa

Yogyakarta dalam Angka, 2004.

Yogyakarta: BPS

Bambang Ismawan (2003). Partisipasi dan Dimensi Keswadayaan: Pengalaman LSM Membangun Keswadayaan Masyarakat.

www.ekonomirakyat.org/edisi15. diambil tanggal 19 Juli 2006

Hari Susanto (2006). Dinamika Penanggulangan Kemiskinan, Tinjauan Historis Era Orde Baru. Jakarta: Khanata Pustaka LP3S

Hastuti, dkk (2003). Buku II Upaya Penguatan Usaha Mikro dalam Rangka Peningkatan Ekonomi Perempuan. Jakarta Lembaga Penelitian Smeru \& Kementerian Pemberdayaan Perempuan.

Lincoln, Y.S \& Guba. (1985). Naturalistic inquiry. London: Sage Publication

Miles, M.B. \& Huberman. A.M. (1994). Qualitative data analysis. London: SAGE

Moleong, L.J. (2004). Metodologi penelitian kualitatf Bandung: PT Remaja Rosdakarya

Patton, M. Q. (1982). Qualitative evaluation methods. London: Sage Publications

Suranto (2006). Strategi Pembelajaran Dengan Focused Based Education Jurnal Ilmiah Teknik Industri, Vol. 4, No. 3, April 2006, hal. 147 - 15 
| Peran Lembaga Swadaya Masyarakat

DIMENSIA, Volume 3, No. 1, Maret 2009 | 51 